\title{
Erratum to: Suicidality and second generation antipsychotics in schizophrenia patients: a case-controlled retrospective study during a 5-year period
}

\author{
Y. Barak • I. Mirecki • H. Y. Knobler • Z. Natan • \\ D. Aizenberg
}

Published online: 23 April 2010

(C) Springer-Verlag 2010

Erratum to: Psychopharmacology (2004) 175:215-219

\section{DOI 10.1007/s00213-004-1801-2}

Due to an unfortunate error, the word "antipsychotics" on the article title was misspelled in the HTML version.

The corrected title is shown above

The online version of the original article can be found at http://dx.doi. org/10.1007/s00213-004-1801-2.

Y. Barak $\cdot$ I. Mirecki $\cdot$ Z. Natan Abarbanel Mental Health Center, 15 KKL Street,

59100 Bat-Yam, Israel

Y. Barak $(\bowtie) \cdot H$. Y. Knobler IDF, Mental Health

e-mail:mdybarak@netvision.net.il

URL: http://dover.idf.il/IDF/English/

D. Aizenberg

Geha Mental Health Center,

Petah-Tikva, Israel 